\title{
Tantangan Dan Peluang Pemanfaatan Teknologi Informasi Dalam Pembelajaran Online Masa Covid-19
}

\author{
Ni Komang Suni Astini \\ STKIP Agama Hindu Amlapura \\ astinisuni2@gmail.com
}

DOI : $10.37329 /$ cetta.v3i2.452

\begin{tabular}{l}
\hline Keywords: \\
\hline Information \\
Technology; Covid- \\
19; Online \\
Lectures; \\
Education Era 4.0. \\
\hline
\end{tabular}

Abstract
This study was conducted to determine the challenges and
opportunities for the use of information technology on online learning
in STKIP Agama Hindu Amlapura during the Covid-19 pandemic.
By using library research methods and survey methods. The samples
used in this study were all college students of STKIP Agama Hindu
Semester II and Semester IV. The Covid-19 pandemic give a
influenced college in Indonesia including the STKIP Agama Hindu
Amlapura with Enforcement of physical distancing policy which then
becomes the basis of the implementation of online lectures, by using
information technology. The most widely used media in online
learning at STKIP Agama Hindu Amlapura are Whatshap group and
Google Classroom because these application is very easy to use. But
there are some problem such as the lacking facilities. Based on the
survey results, 50\% of students do not have a laptops, and 80\% of
students are difficult to get signals and wasteful in using a data plan
because many students live far from urban areas. The study was not
effective because as many as $61.5 \%$ of students stated they never used
online learning media before the co-19 pandemic. But the fact by
using online learning is a trigger for the acceleration of the process of
digital transformation of Indonesian education. Before pandemic
some of discourse, supporting policies, and socialization about the era
of education 4.0 was not successful. But Covid-19 give an
extraordinary impact on digital transformation towards the
educational era 4.0.

\begin{tabular}{l}
\hline Kata Kunci: \\
\hline Information \\
Technology,; \\
Covid-19; \\
Perkuliahan \\
Online; Era \\
Pendidikan 4.0. \\
\hline
\end{tabular}

\begin{tabular}{l} 
Abstrak \\
\hline Penelitian ini dilakukan bertujuan untuk mengetahui \\
tantangan dan peluang pemanfaatan information technology \\
terhadap pembelajaran online di STKIP Agama Hindu \\
Amlapura pada masa pandemi Covid-19.Dengan \\
menggunakan metode penelitian kepustakaan dan metode \\
survey. Sampel yang digunakan dalam penelitian ini adalah \\
semua mahasiswa STKIP Agama Hindu Semester II dan \\
Semester IV. Pandemi Covid-19 sangat memberikan pengaruh \\
\hline
\end{tabular}


terhadap pendidikan tinggi di Indonesia termasuk STKIP Agama Hindu Amlapura. Pemberlakuan kebijakan physical distancing yang kemudian menjadi dasar pelaksanaan perkuliahan online, dengan memanfaatkan teknologi informasi. Media yang paling banyak digunakan dalam perkuliahan online di STKIP Agama Hindu Amlapura yaitu Whatshap group dan Google Classroom karena aplikasi ini sangat mudah digunakan. Namun ada beberapa kendala yang dialami seperti fasilitas yang belum memadai. Berdasarkan hasil survey menyatakan 50\% mahasiswa yang belum mempunyai laptop, sebanyak $80 \%$ mahasiswa menyatakan susah mendapatkan sinyal dan boros penggunaan paket data ini disebabkan karena banyak mahasiswa yang tinggal jauh dari daerah perkotaan. Perkuliahan dirasa kurang efektif karena sebanyak $61,5 \%$ mahasiswa yang menyatakan belum pernah menggunakan media perkuliahan online sebelum pandemi covid-19.Namun ternyata pemberlakukan perkuliahan online menjadi pemicu percepatan proses transformasi digital pendidikan Indonesia. Jika sebelumnya berbagai wacana, kebijakan pendukung, serta sosialisasi tentang era pendidikan 4.0 belum berhasil.Namun Covid-19 justru memberikan dampak luar biasa terhadap transformasi digital menuju era pendidikan 4.0.

\section{Pendahuluan}

Menularnya Covid-19 membuat dunia menjadi resah, termasuk di Indonesia. Covid-19 merupakan jenis virus yang baru sehingga banyak pihak yang tidak tahu dan tidak mengerti cara penanggulangan virus tersebut.Seluruh dunia kini disibukkan dengan berbagai upaya pencegahan Covid-19 untuk menahan lonjakan pasien positif karena hingga saat ini masih belum ditemukan obat ataupun vaksinnya. Dengan adanya virus Covid-19 pemerintah membuat beberapa kebijakan untuk menghentikan penyebaran wabah ini, seperti melakukan lockdown di daerah yang sudah termasuk ke dalam zona merah penyebaran virus, atau physical quarantine untuk menghindari virus secara kontak fisik. Pemerintah Republik Indonesia juga menerbitkan berbagai protokol kesehatan. Protokol tersebut dilaksanakan di seluruh indonesia oleh pemerintah dengan dipandu secara terpusat oleh Kementrian Kesehatan RI (2020).

Lonjakan kasus positif Covid-19 bukan hanya berdampak pada dunia ekonomi, tetapi dirasakan pula oleh dunia pendidikan. Pemberlakuan kebijakan physical distancing yang kemudian menjadi dasar pelaksanaan belajar di rumah, dengan memanfaatkan teknologi informasi yang berlaku secara tiba-tiba, tidak jarang 
membuat pendidik, siswa, mahasiswa dan orang tua kaget karena tidak siap. Pendidik merasa kaget karena harus mengubah sistem pembelajaran yang awalnya belajar secara tatap muka kini semua pembelajaran dilakukan secara daring (online).

Kebijakan pelaksanaan pendidikan daring yang dilakukan oleh sekolah dan juga perguruan tinggi di Indonesia adalah menyikapi pandemi Covid-19 yang melanda hampir seluruh dunia. Kementrian Pendidikan dan kebudayaan RI mendorong penyelenggaraan proses pembelajaran dilakukan dengan daring. Hal ini sesuai dengan Surat Edaran Mendikbud RI nomor 3 tahun 2020 tentang Pencegahan Corona Virus Disease (COVID-19) pada Satuan Pendidikan, dan Surat Sekjen Mendikbud nomor 35492/A.A5/HK/2020 tanggal 12 Maret 2020 perihal Pencegahan Penyebaran Corona Virus Disease (Covid-19). Di samping juga mengikuti edaran dan himbauan dari masing-masing Pemerintah Daerah domisili Perguruan Tinggi.

Teknologi Informasi adalah solusi dari pemberlakuan perkuliahan secara daring. Banyak media informasi yang digunakan oleh pendidik untuk melakukan pembelajaran secara daring (Lathipatud Durriyah \& Zuhdi, 2018; Kassem, 2018; Bal, 2018; Manca \& Ranieri, 2013). Teknologi informasi sebagai pendukung terlaksananya pembelajaran online pada masa pandemi ini di antaranya adalah e-learning, rumah belajar, Edmodo, EdLink, Moodle, Google Classroom, kelas online Schoology. Mahasiswa harus siap dengan pembelajaran yang dilakukan secara online. Setelah tiga bulan pemberlakuan pembelajaran daring banyak keluhan yang dialami oleh mahasiswa karena ketidaksiapan fasilitas yang dimiliki oleh mahasiswa.

Perkuliahan online juga diterapkan di STKIP Agama Hindu Amlapura yang mengharuskan semua dosen dan mahasiswa mau tidak mau harus melek teknologi. Dosen harus menyiapkan materi berupa bahan ajar dan video tutorial terlebih dahulu sebelum melakukan perkuliahan online. Begitu pun mahasiswa harus belajar lebih giat untuk bisa memahami materi yang diberikan oleh dosen secara online. Proses pembelajaran online belum dilakukan secara maksimal karena ketidaksiapan dosen dan mahasiswa sehingga perlu penyesuaian terlebih dahulu. Banyak mahasiswa terbatas akan fasilitas yang dimiliki untuk mendukung perkuliahan online. Mulai dari keterbatasan sinyal, borosnya penggunaan paket data, banyak mahasiswa yang belum mempunyai laptop, bahkan banyak mahasiswa yang tidak tinggal di kota tetapi tinggal di pedalaman/pegunungan yang jauh dari akses internet. Kondisi inilah yang bisa mengakibatkan kesenjangan pembelajaran semakin kuat. Hal tersebut 
mengindikasikan bahwa sesungguhnya banyak tantangan yang dihadapi dalam pembelajaran online dengan pemanfaatan teknologi informasi. Namun, di samping tantangan tersebut, tentu juga ada peluang-peluang pemanfaatan teknologi informasi yang perlu dikembangkan oleh dosen secara inovatif dan tentunya akan sangat bermanfaat dalam dunia pemebalajaran dan era digital.

Kajian semacam ini sudah pernah dilakukan oleh Ketut Sudarsana, Pusparani, Selasih, Juliantari, \& Wayan Renawati (2019) yang menemukan sejumlah peluang dan tantangan yang dihadapi dalam pemanfaatan teknologi informasi untuk menunjang kegiatan pendidikan. Sementara itu, sebelumnya Juliantari, Sudarsana, Sutriyanti, Temon Astawa, Hendrawathy Putri, \& Saddhono (2018) juga pernah melakukan kajian terhadap pemanfaatan teknologi informasi dalam kegiatan evaluasi melalui penggunaan game interaktif. Hasilnya menunjukkan keefektifan teknologi informasi tersebut dalam menunjang pembelajaran dan evaluasi asalkan digunakan secara tepat dan daya dukung memadai. Walaupun kajian tersebut tampak serupa dengan penelitian ini, situasi Covid-19 yang berdampak pada psikologi pebelajaran menyebabkannya menjadi berbeda. Di samping itu, subjek yang tersentuh oleh teknologi informasi ini pun berbeda, sehingga ada hal baru yang tentunya dapat mendukung kedua penelitian terdahulu tersebut.

Berdasarakan pemaparan latar belakang masalah di atas, timbul ketertarikan untuk melakukan penelitian yang bertujuan untuk mendeskripsikan peluang dan tantangan penggunaan teknologi informasi dalam pembelajaran online di STKIP Agama Hindu Amlapura pada masa pandemi Covid-19.

\section{Metode}

Penelitian ini menggunakan penelitian kepustakaan dan metode survey. Penelitian kepustakaan merupakan suatu penelitian yang digunakan dalam mengumpulkan informasi dan data dengan bantuan berbagai macam material yang ada di perpustakaan seperti dokumen, buku, majalah, kisah-kisah sejarah, berita, dan sebagainya. Sementara itu, menurut ahli penelitian kepustakaan merupakan kajian teoritis, referensi serta literatur ilmiah lainnya yang berkaitan dengan budaya, nilai dan norma yang berkembang pada situasi sosial yang diteliti (Sugiyono, 2012). Dalam penelitian ini, pengumpulan data diperoleh dari berita dan artikel-artikel pada jurnal online. Peneliti melakukan penelusuran artikel dengan menggunakan kata kunci “ 
Dampak Covid-19”, “Pembelajaran Daring”. Penelitian survey dilakukan dengan cara menyebarkan kuesioner menggunakan google form. Pengumpulan data primer penelitian ini dengan cara menyebarkan kuesioner ke responden (Creswell, 2014). Responden penelitian ini adalah mahasiswa STKIP Agama Hindu Amlapura Semester 2 dan semester 4 dari jurusan Pendidikan Agama Hindu, Jurusan Pendidikan Bahasa Bali, Jurusan Pendidikan Bahasa Inggris, dan Jurusan Pendidikan Guru Sekolah Dasar, yang berjumlah 200 orang. Data yang terkumpul dari beragam cara pengumpulan data tersebut selanjutnya diolah dan dipadukan untuk mendapatkan interpretasi terkait dengan tantangan dan peluang pemanfaatan teknologi informasi dalam kegiatan pembelajaran online pada masa pandemi Covid-19.

\section{Hasil dan Pembahasan}

Kebijakan pelaksanaan perkuliahan daring yang dilakukan oleh semua perguruan tinggi di Indonesia adalah menyikapi pandemi Covid-19 yang melanda hampir seluruh dunia. Kementerian Pendidikan dan kebudayaan RI mendorong penyelenggaraan proses pembelajaran dilakukan dengan daring. Hal ini sesuai dengan Surat Edaran Mendikbud RI nomor 3 tahun 2020 tentang Pencegahan Corona Virus Disease (COVID-19) pada Satuan Pendidikan, dan Surat Sekjen Mendikbud nomor 35492/A.A5/HK/ 2020 tanggal 12 Maret 2020 perihal Pencegahan Penyebaran Corona Virus Disease (Covid-19).

Pemberlakuan kebijakan physical distancing yang kemudian menjadi dasar pelaksanaan perkuliahan online, dengan memanfaatkan teknologi informasi yang berlaku secara tiba-tiba, membuat dosen dan mahasiswa kaget karena tidak siap. Beberapa dosen merasa kaget karena harus mengubah sistem pembelajaran yang awalnya belajar secara tatap muka kini semua pembelajaran dilakukan secara online. Secara rinci temuan yang diperoleh dalam penelitian ini diuraikan sebagai berikut.

\section{Tantangan Pemanfaatan Teknologi Informasi dalam Pembelajaran Online}

Berdasarkan data kuesioner diperoleh informasi tentang perkuliahan online selama pandemi Covid-19 bahwa masih banyak mahasiswa STKIP Agama Hindu Amlapura yang belum siap akan adanya perkuliahan online. 
Tabel 1 Tantangan yang Dihadapi oleh Mahasiswa

\begin{tabular}{|c|l|c|}
\hline No & \multicolumn{1}{|c|}{ Aspek } & Persentase Mahasiswa \\
\hline 1 & Belum mempunyai fasilitas laptop & $50 \%$ \\
\hline 2 & $\begin{array}{l}\text { Hanya menggunakan fasilitas handphone dalam } \\
\text { pembelajaran online }\end{array}$ & $50 \%$ \\
\hline 3 & $\begin{array}{l}\text { Sebelum Covid-19 ini tidak pernah melaksanakan } \\
\text { pembelajaran daring }\end{array}$ & $61,5 \%$ \\
\hline
\end{tabular}

Berdasarkan tabel di atas 50\% mahasiswa menyatakan belum mempunyai fasilitas laptop dan 50\% mahasiswa dalam perkuliahan online menggunakan handphone sebagai media perkuliahan online. Data ini menunjukan masih banyak mahasiswa yang belum bisa mengikuti perkuliahan online secara maksimal.

Perubahan paradigma pembelajaran konvensional ke daring, walaupun tidak sulit, akan tetapi memerlukan waktu yang lama. Sebab hal tersebut sangat berhubungan dengan perubahan paradigma budaya akademik. Sebagaimana hasil survei terhadap mahasiswa diperoleh hasil bahwa 61,5\% mahasiswa sebelum Covid-19 ini tidak pernah melaksanakan pembelajaran daring. Berdasarkan data survei di atas, menunjukkan bahwa mahasiswa belum siap untuk melaksanakan pembelajaran daring ini, karena menyangkut budaya akademik, yang meliputi nilai, sikap, pengetahuan dan keterampilan, serta kesiapan sarana dan prasarana yang berkaitan dengan literasi informasi di kalangan mahasiswa. Idealnya, adanya perubahan kebijakan yang menyangkut paradigma pembelajaran ini dijadikan sebagai momentum bagi para mahasiswa untuk bebas dan kritis mencari informasi pengetahuan secara digital. Demikian pula kesempatan belajar bisa leluasa, karena tidak terikat oleh kehadiran tatap muka (Bauer, 2005). Mahasiswa bisa mengatur waktunya secara leluasa untuk memenuhi tuntutan tugas belajarnya. Dengan demikian, mahasiswa akan menjadi literat terhadap informasi berkaitan dengan keperluan akademiknya dan akan terus bertambah (Bal, 2018). Akan tetapi, kenyataannya justru malah sebaliknya. Adanya perubahan paradigma pembelajaran tersebut, mahasiswa banyak mengeluh, sebagai bukti ketidak siapan mahasiswa secara internal yang berkaitan dengan nilai, sikap, pengetahuan, dan keterampilan memperoleh, mengevaluasi, dan mengorganisasikan informasi. 
Ketidaksiapan mahasiswa ini juga disebabkan oleh letak geografis mahasiswa STKIP Agama Hindu Amlapura yang kebanyakan jauh dari perkotaan, sehingga banyak mahasiswa yang susah mendapatkan koneksi internet. Berdasarkan hasil survei ditemukan bahwa sebanyak $80 \%$ mahasiswa yang mengalami kendala masalah sinyal dan borosnya penggunaan paket data ketika dilaksanakan perkuliahan online. Ini menjadi perhatian penting bagi lembaga STKIP Agama Hindu Amlapura, karena banyak mahasiswa yang mengharapkan mendapatkan subsidi biaya administrasi. Mengingat belum pastinya kapan perkuliahan akan berjalan normal kembali.

Menurut surat edaran Kemendikbud No 1 tahun 2020 tentang Pencegahan Penyebaran Corona Virus Disease (Covid-19) di perguruan tinggi, kementerian pendidikan dan kebudayaan point ke-5 yang menyatakan "Menyelenggarakan pembelajaran jarak jauh sesuai dengan kondisi PT masing-masing, dan menyarankan mahasiswa untuk melakukan pembelajaran dari rumah dengan pembelajaran daring baik synchronous maupun asynchronous, melalui platform: Google Classroom/ Edmodo/ Schoology/ Classdojo (for kids), untuk merekam materi bentuk video melalui: Camtasia/ Screencast-O-Matic/ Seesaw/ Xrecorder, dan untuk latihan dapat melalui Quizlet (flashcard dan diagram), Quizizz (homework) atau Kahoot" (Kemendikbud, 2020).

Berdasarkan surat edaran tersebut Sistem Perkuliahan di STKIP Agama Hindu Amlapura sudah dilakukan dengan perkuliahan jarak jauh dengan menggunakan platform Google Classroom, Edmodo, EdLink, Scholooy, Zoom, dan Whatshap Group. Berdasarkan hasil survei dari penggunaan aplikasi perkuliahan online menyatakan bahwa aplikasi yang paling banyak dimanfaatkan oleh dosen dan mahasiswa STKIP Agama Hindu Amlapura adalah Google Classroom sebanyak 40\%, kedua Whatshap group sebanyak 39\%, ketiga Schoology sebanyak 15\%, kemudian Edmudo 3\%, Edlink 2\%, dan Zoom 1\%. Penggunaan media Google classroom dan Whatsapp Group ini menjadi sangat diminati oleh dosen dan mahasiswa STKIP Agama Hindu Amlapura karena sangat mudah dipahami dan bisa terjangkau oleh sinyal dan paket data yang dimiliki mahasiswa. Agar perkuliahan menjadi lebih menarik dan mahasiswa bisa mengerti dengan materi yang disampaikan, maka diperlukan kreativitas mengajar dari dosen masing-masing, seperti memberikan penjelasan materi dengan menggunakan video, perkuliahan dipadukan dengan melakukan video conference Zoom atau dengan aplikasi lain kepada mahasiswa untuk menjelaskkan materi yang akan diberikan kepada mahasiswa. 


\section{Peluang Pemanfaatan Teknologi Informasi dalam Pembelajaran Online}

Transformasi digital sektor pendidikan di indonesia bukanlah suatu wacana yang baru berbagai perbincangan, regulasi pendukung dan upaya konkret menerapkan transformasi digital di lingkungan perguruan tinggi dan semua tingkat sekolah di Indonesia. Jika sebelumnya berbagai wacana, kebijakan pendukung, serta sosialisasi tentang era industri 4.0 belum berhasil membuat industri pendidian universitas, institut, sekolah tinggi, politeknik, akademi, hingga sekolah dasar menengah) mencapai progress signifikan pada transformasi digital pendidikan Indonesia, Covid-19 atau Virus Corona justru memberikan dampak luar biasa dalam aspek ini. (Suteki, 2020).

Ditinjau dari berbagai aspek, jelas Covid-19 adalah musibah yang memberi dampak negatif kepada hampir semua sektor kehidupan manusia. Terutama upaya pencegahan penyebaran Covid-19 melalui Pembatasan Sosial Berskala Besar (PSBB) atau Lockdown dengan berbagai himbauan dirumahaja work from home,Learn From Home, Stay Home dan lain-lain. Namun tidak dapat dipungkiri bahwa musibah melalui pandemi Covid-19 juga membawa berbagai dampak positif, seperti kondisi alam yang menjadi lebih baik, dan di bidang pendidikan ternyata menjadi pemicu percepatan proses transformasi digital pendidikan Indonesia.

Seluruh perguruan tinggi dan sekolah di Indonesia menghentikan aktivitas belajar mengajar tatap muka termasuk STKIP Agama Hindu Amlapura. Namun, tentu saja proses belajar mengajar tidak boleh berhenti, saat ini semua harus menjalankan belajar online. Mau tidak mau, bisa tidak bisa, merasa gaptek atau tidak gaptek. Hasilnya saat ini dominan dosen, guru, mahasiswa dan siswa mulai mahir menggunakan berbagai perangkat dan media pendukung belajar online. Walaupun mungkin menghadapi berbagai kendala dan berbagai keterbatasan. Bagaimanapun ini adalah suatu kemajuan yang layak disyukuri dan membiasakan diri untuk memanfaatkan teknologi dalam proses pembelajaran.

Webinar merupakan singkatan dari web seminar, yaitu seminar yang dilakukan melalui aplikasi berbasis internet seperti zoom, google meet, jitsi dan lain-lain. Dengan webinar memungkinkan terjadi proses knowledge transfer tanpa batasan jarak dan ruang. Semenjak pembatasan aktivitas sosial untuk pencegahan Covid-19 di Indonesia banyak Dosen dan para pendidik melakukan webinar, terdapat begitu banyak kegiatan webinar yang telah dilaksanakan, termasuk beberapa dosen STKIP Agama 
Hindu Amlapura. Ada webinar yang berbayar dan juga banyak yang menawarkan webinar berkualitas secara gratis. Ini tentu merupakan salah satu indikasi perkembangan positif bagi proses transformasi digital pendidikan di Indonesia.

Education 4.0 dapat dilihat sebagai sebuah respons kreatif di mana manusia memanfaatkan teknologi digital, open sources contents dan global classroom dalam penerapan pembelajaran sepanjang hayat (lifelong learning), flexible education system, dan personalized learning, untuk memainkan peran yang lebih baik di tengah-tengah masyarakat. Di sisi lain, new normal pembelajaran secara e-learning bukanlah jawaban dari sebuah pertanyaan, tetapi adaptasi dari sebuah kondisi yang semua orang “terpaksa" melakukannya.

Pascapandemi Covid-19 nantinya, new normal pendidikan yang telah dimulai seharusnya diteruskan dan disempurnakan hingga memenuhi konsep blended learning, yakni sebuah konsep pendidikan yang mengkobinasikan metode kuliah tatap muka di ruang kelas dengan e-learning, dan pada gilirannya, dunia pendidikan akan benarbenar berada dalam era education 4.0. Terkait e-learning di perguruan tinggi, jika yang menjadi ukuran adalah "dapat dilakukan", maka tidak bisa dipungkiri bahwa semua kampus dapat melakukannya.Pengajar maupun peserta didik dipacu untuk memahami setidaknya penggunaan teknologi digital. Di sisi lain peserta didik juga dipaksa untuk mengeksplor teknologi informasi dan menyalurkan kreatifitasnya melalui inovasi-inovasi dalam tugas-tugas yang diberikan.

Ada berbagai platform teknologi informasi yang berpeluang untuk dimanfaatkan dalam mendukung kegiatan pembelajaran daring dan sekaligus berpeluang pula memaksa para dosen agar melek teknologi informasi. Beberapa di antaranya sebagai berikut: e-learning, Rumah belajar, Edmodo, EdLink, Moodle, Google Classroom, kelas online Schoology.

a. E-learning adalah teknologi informasi dan komunikasi untuk mengaktifkan siswa untuk belajar kapanpun dan di manapun Dahiya dalam (Hartanto, 2016). E-learning memiliki dua tipe, yaitu: pertama Synchronous. Synchronous berarti pada waktu yang sama. Proses pembelajaran terjadi pada saat yang sama antara pendidik dan peserta didik. Hal ini memungkinkan interaksi langsung antara pendidik dan peserta didik secara online. Synchronous training merupakan gambaran dari kelas nyata, namun bersifat maya (virtual) dan semua peserta didik terhubung melalui internet. Synchronous training sering juga disebut 
sebagai virtual classroom. Kedua, Asynchronous berarti tidak pada waktu bersamaan. Peserta didik dapat mengambil waktu pembelajaran berbeda dengan pendidik memberikan materi. Asynchronoustraining populer dalam e-learning karena peserta didik dapat mengakses materi pembelajaran dimanapun dan kapanpun. Peserta didik dapat pemaksanakan pembelajaran dan menyelesaikannnya setiap saat sesuai rentang jadwal yang sudah ditentukan. Pembelajaran dapat berbentuk bacaan, animasi, simulasi, permainan edukatif, tes, quis dan pengumpulan tugas.

b. Edmodo merupakan aplikasi yang aman untuk digunakan baik oleh guru/dosen maupun oleh siswa/mahasiswa. Jeff O'Hara sebagai platform pembelajaran untuk berkolaborasi dan terhubung antara siswa dan guru dalam berbagi konten pendidikan, mengelola proyek atau tugas dan menangani pemberitahuan setiap aktivitas. Dalam definisi lain, Edmodo adalah pembelajaran berbasis jejaring sosial yang aman dan gratis dalam memudahkan guru untuk membuat dan mengelola kelas virtual sehingga siswa dapat terhubung dengan teman sekelas dan guru kapan saja dan dimana saja (Balasubramanian, 2014). Definisi Edmodo lainnya yaitu bahwa Edmodo adalah aplikasi edukasi dengan platform media sosial dan cloud menyerupai facebook yang dapat digunakan dalam pembelajaran. Sejalan dengan pandangan Gatot, Sudibjo (2013) mengemukakan bahwa edmodo diciptakan menggunakan konsep yang mirip dengan facebook, di mana tujuan pembuatannya adalah khusus untuk bidang pendidikan yang dapat mendukung proses pembelajaran secara online.

c. EdLink adalah aplikasi berbasis android yang dikhususkan untuk dunia pendidikan guna membantu dosen dan mahasiswa dalam proses perkuliahan. Beberapa manfaat Edlink untuk dosen adalah untuk menghemat waktu, menjaga kelas tetap teratur, meningkatkan komunikasi dengan mahasiswa dan masih banyak lainnya. Bukan hanya membantu dosen namun juga sangat bermanfaat untuk mahasiswa dimana para mahasiswa bisa lebih update tentang informasi kampus, dan juga memudahkan dalam proses perkuliahan.

d. Moodle adalah sebah platform untuk belajar (learning platform) yang didesain khusus bagi pendidik, admin dan mahasiswa. Moodle sebenarnya merupakan singkatan dari Modular Object-Oriented Dynamic Learning Environment. Platform ini tergolong CMS namun khusus bagi kepentingan edukasi. 
e. Google Classroom atau ruang kelas Google merupakan suatu serambi pembelajaran campuran untuk ruang lingkup pendidikan yang dapat memudahkan pengajar dalam membuat, membagikan dan menggolongkan setiap penugasan tanpa kertas, Afrianti ( dalam Yustianti dan Novita, 2019). Google Classroom digunakan untuk memaksimalkan proses penyampaian materi kepada peserta didik tetapi dilakukan secara online sehingga materi bisa tersampaikan secara keseluruhan. Google Classroom adalah layanan berbasis internet yang disediakan oleh Google sebagai sebuah system e-learning. Service ini didesain untuk membantu pengajar membuat dan membagikan tugas kepada pelajar secara paperless (Hakim, 2016).

f. Schoology merupakan sosial network berbasis lingkungan sekolah (school based environment) yang dikembangkan oleh Nicolas Borg and Jeff O'Hara tahun 2008, schoology ditujukan untuk penggunaan bagi guru, siswa dan orang tua siswa. Tampilan Schoology hampir sama dengan jejaring sosial facebook, situs jejaring sosial facebook sudah lumrah dikalangan remaja bahkan anak usia SD pun sudah mengenal apa yang namanya facebook.

g. Zoom adalah aplikasi pertemuan HD gratis dengan video dan berbagi layar hingga 100 orang. Zoom merupakan aplikasi komunikasi dengan menggunakan video. Aplikasi tersebut dapat digunakan dalam berbagai perangkat seluler, desktop, hingga telepon dan system ruang.

h. Whatsapp merupakan salah satu media komunikasi yang sangat popular yang digunakan saat ini, Whatshapp merupakan salah satu aplikasi yang digunakan untuk melakukan percakapan baik menggunakan teks, suara, maupun video. Whatshapp untuk tetap terhubung dengan teman keluarga, kapanpun dan dimanapun. Whatshapp gratis dan menawarkan pengalaman bertukar pesan dan panggilan yang sederhana, aman, reliable, tersedia pada telepon diseluruh dunia. Selanjutnya Menurut Niken, sekretaris Jendral Kementrian Komunikasi dan Informatika, whatshapp adalah aplikasi yang paling diminati masyarakat dalam berkomunikasi lewat internet. " $83 \%$ dari 171 juta pengguna internet kita adalah pengguna whatshapp yang menghubungkan antara masyarakat".

Dari beberapa platform mode digital yang disebutkan di atas tersebut, Whatsapp-lah yang paling familiar di kalangan mahasiswa dan dosen STKIP Agama Hindu Amlapura, karena sebelum masa pandemi Covid-19 ini, mahasiswa dan dosen 
juga sudah intensif berkomunikasi dan berinteraksi terkait pembelajaran melalui Whatsapp grup. Namun, pembelajaran online pada masa pandemi ini hendaknya dapat dimanfaatkan oleh dosen untuk mengembangkan kompetensi digital sehingga mode digital yang dimanfaatkan oleh setiap dosen bisa lebih variatif. Hal ini bertujuan untuk menghindari kebosanan mahasiswa dalam belajar dan menyerap informasi terkait materi ajar, di samping juga untuk menghindari pola-pola monoton yang dilakukan oleh sebagaian besar dosen.

Sistem konvensional yang terjadi selama ini semestinya dipadukan dengan media komunikasi multimedia, khususnya sejak ditemukannya media komunikasi multimedia ini. Karena sifat internet yang dapat dihubungi kapan saja, itu berarti siswa dapat memanfaatkan program pendidikan yang disediakan di internet kapan saja sesuai dengan waktu luang mereka, sehingga ruang dan kendala waktu yang mereka hadapi dalam menemukan sumber belajar dapat diatasi. Dengan perkembangan pesat di bidang telekomunikasi, multimedia, dan teknologi informasi; mendengarkan ceramah, membuat catatan di atas kertas tentu sudah ketinggalan zaman. Menurut Abdulhak \& Darmawan (2005), terdapat klasifikasi pemanfaatan ICT (Information, Comunication and Technology) ke dalam tiga jenis, yaitu: pertama, ICT sebagai media (alat bantu) pendidikan yaitu hanya sebagai pelengkap untuk memperjelas uraian yang disampaikan. Kedua, ICT sebagai sumber yakni sebagai sumber informasi dan mencari informasi. Ketiga, ICT sebagai sistem pembelajaran.

Sejalan dengan perkembangan ICT (Information, Comunication and Technology), muncul berbagai model pembelajaran secara online. Selanjutnya muncul istilah sekolah berbasis web (web-school) atau sekolah berbasis internet (cyber-school), yang menggunakan fasilitas internet. Bermula dari kedua istilah tersebut, muncullah berbagai istlah baru dalam pembelajaran yang menggunakan internet, seperti, online learning, distance learning, web-based learning, e-learning(Kuntarto, 2016)

Perkembangan teknologi yang sangat pesat saat ini menjadi gerbang untuk datangnya revolusi industri 4.0 atau industri 4.0. Menurut (Davis, 2011)industri 4.0 ini sebagaicyberphysical systems yang berarti teknologi bukan lagi menjadi 'alat' melainkan tertanam pada kehidupan masyarakat. Artificial Intelligence, nanotechnology, biotechnology, autonomus vehicles, dan 3D printing merupakan contoh semakin luasnya perkembangan teknologi saat ini. Kecepatan, jangkauan/cakupan, dan dampak merupakan tiga alasan dari Schwab (World Economic Forum, 2016) yang menjelaskan 
bahwa transformasi teknologi saat ini bukan perpanjangan dari revolusi industri ketiga, melainkan kedatangan revolusi industri 4.0. Beberapa aplikasi tersebut bisa menjadi menjadi langkah awal bagi perguruan tinggi saat menyusun e-learning dalam menerapkan Blended Learning guna mewujudkan Education 4.0 yang akan menjadi New Normal di era Industrial Revolution 4.0 pasca pandemi Covid-19.

\section{Kesimpulan}

Pandemi covid-19 sangat memberikan pengaruh terhadap pendidikan tinggi di Indonesia termasuk STKIP Agama Hindu Amlapura. Pemberlakuan kebijakan physical distancing yang kemudian menjadi dasar pelaksanaan perkuliahan online, dengan memanfaatkan teknologi informasi seperti whatshap group,Edmodo, EdLink, Moodle, Google Classroom, kelas online Schoology. Media yang paling banyak digunakan dalam pembelajaran online di STKIP Agama Hindu Amlapura yaitu Whatshap group dan Google Classroom karena aplikasi ini sangat mudah digunakan. Namun ada beberapa kendala yang dialami seperti fasilitas yang belum memadai. Berdasarkan hasil survey menyatakan 50\% mahasiswa yang belum mempunyai laptop, 80\% mahasiswa menyatakansusah mendapatkan sinyal dan boros penggunaan paket data, ini disebabkan karena banyak mahasiswa yang tinggal jauh dari daerah perkotaan. Banyak yang merasakan perkuliahan online tidak efektif, ini disebabkan karena belum terbiasa melakukan perkuliahan secara online sehingga perlu penyesuaian terlebih dahulu. Hal ini juga disebabkan karena sebelum pandemi covid-19 sebanyak 61,5\% mahasiswa yang menyatakan belum pernah menggunakan media perkuliahan online.

Ditinjau dari berbagai aspek, jelas Covid-19 adalah musibah yang memberi dampak negatif kepada hampir semua sektor kehidupan manusia termasuk dalam bidang pendidikan. Namun tidak dapat dipungkiri bahwapandemi Covid-19 juga memberikan kesempatan bagi lembaga pendidikan untuk melek teknologi dan dengan pemberlakukan perkuliahan online ternyata menjadi pemicu percepatan proses transformasi digital pendidikan Indonesia. Jika sebelumnya berbagai wacana, kebijakan pendukung, serta sosialisasi tentang era industri 4.0 belum berhasil membuat industri pendidian universitas, institut, sekolah tinggi, politeknik, akademi, hingga sekolah dasar menengah) mencapai progress signifikan pada transformasi digital pendidikan Indonesia, Covid-19 atau Virus Corona justru memberikan dampak luar biasa terhadap transformasi digital menuju era pendidikan 4.0. 


\section{Daftar Pustaka}

Abdulhak, I., \& Darmawan, D. (2005). Teknologi Pendidikan. Bandung: PT. Remaja Rosdakarya.

Balasubramanian, K. \&. (2014). Student Preference Towards The Use Of Edmodo As A Learning Platform To Create Responsible Learning Environment. Prosiding, Asia Euro Conference. Selangor: School of Hospitality, Tourism and Culinary Arts, Taylor's.

Bal, M. (2018). Reading and Writing Experiences of Middle School Students in the Digital Age: Wattpad Sample. International Journal of Education and Literacy Studies, 6(2), 89. https://doi.org/10.7575/aiac.ijels.v.6n.2p.89

Bauer, J. (2005). Toward Technology Integration in the Schools: Why It Isn 't Happening. 13, 519-546.

Creswell, A. J. (2014). Educational Research: Planning, Conducting and Evaluating Quantitative

Davis, I. (2011). Instructional Technique. New York: McGraw Hill Book Company.

Fathiyah Isbaniah, d. (Maret 2020). Pedoman Pencegahan Pengendalian Coronavirus Disease (COVID-19). Jakarta: Kementrian Kesehatan RI.

Hakim. (2016). Efektifitas Penggunaan E-Learning Moodle, Google Classroom Dan Edmodo. I-Statement.

Hartanto, W. (2016). Penggunaan ELearningSebagai Media Pembelajaran. Jurnal UNEJ.

Juliantari, N. K., Sudarsana, I. K., Sutriyanti, N. K., Temon Astawa, I. N., Hendrawathy Putri, I. D. A., \& Saddhono, K. (2018). Educational Games Based in Information Technology as Innovation Evaluation Activity in Learning. Journal of Physics: Conference Series, 1114(1). https:// doi.org/10.1088/1742-6596/1114/1/012041

Kassem, M. A. (2018). Balancing Technology With Pedagogy in English Language Classroom: Teachers ' Perspective. 6(December), 1-19.

Kemendikbud. (2020). Surat Edaran Nomor 1 Tahun 2020 tentang Pencegahan Penyebaran Corona Virus Disease (Covid019) Di Perguruan Tinggi, Kementrian Pendidikan dan Kebudayaan.

Ketut Sudarsana, I., Pusparani, K., Selasih, N. N., Juliantari, N. K., \& Wayan Renawati, P. (2019). Expectations and challenges of using technology in education. Journal of Physics: Conference Series, 1175(1). https://doi.org/10.1088/17426596/1175/1/012160 
Kuntarto, E. d. (2016). Pengembangan Model Pembelajaran Blended Learning pada aspek Learning Design dengan Platform media sosial online Sebagai Pendukung Perkuliahan Mahasiswa.

Lathipatud Durriyah, T., \& Zuhdi, M. (2018). Digital Literacy With EFL Student Teachers: Exploring Indonesian Student Teachers' Initial Perception About Integrating Digital Technologies Into a Teaching Unit. International Journal of $\begin{array}{llll}\text { Education and } & \text { Literacy }\end{array}$ https:// doi.org/10.7575/aiac.ijels.v.6n.3p.53

Manca, S., \& Ranieri, M. (2013). Is it a tool suitable for learning? A critical review of the literature on Facebook as a technology-enhanced learning environment. 487-504. https:// doi.org/10.1111/jcal.12007

Sugiyono. (2012). Metode Penelitian Kuantitatif Kualitatif dan RED. Alfabeta.

Suteki. (2020, Mei 02). Covid-19 Picu Percepatan Transformasi Digital Pendidikan Indonesia. Retrieved from https://suteki.co.id/covid-19-picu-percepatan-transformasidigital-pendidikan-indonesia/ 